\title{
TESTING BIOCHAR AS A POSSIBLE WAY TO AMELIORATE SLIGHTLY ACIDIC SOIL AT THE RESEARCH FIELD LOCATED IN THE DANUBIAN LOWLAND
}

\author{
Ján HORÁK \\ Slovak University of Agriculture in Nitra, Slovak Republic
}

\begin{abstract}
One-year field experiment with spring barley (Hordeum vulgare L.) was carried out to evaluate the effect of biochar amendment on

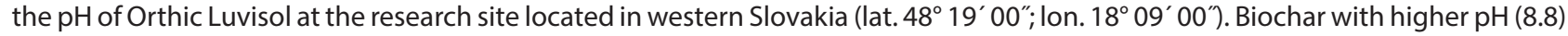
was applied to slightly acidic soils with the initial $\mathrm{pH}$ at 5.6. The field experiment consisted of control, 10 and $20 \mathrm{t} \mathrm{ha}^{-1}(\mathrm{~B} 0, \mathrm{~B} 10, \mathrm{~B} 20)$ of biochar application to soils combined with three levels of nitrogen fertilization $\left(0,40\right.$ and $\left.80 \mathrm{~kg} \mathrm{~N} \mathrm{ha}^{-1}\right)(\mathrm{NO}, \mathrm{N} 40, \mathrm{~N} 80)$. The soil pH (KCl) at depth 0-10 cm was measured once a month (March - October, 2014). Application of both biochar rates (10 and $\left.20 \mathrm{tha}{ }^{-1}\right)$ increased $\mathrm{pH}$ (in all months) with the magnitude of $0.13-1.09$ units in all three fertilization levels $\left(0,40\right.$ and $\left.80 \mathrm{~kg} \mathrm{~N} \mathrm{ha}^{-1}\right) \mathrm{compared}^{-1}$ to the control one. However, the significant increase $(p<0.05)$ was found only in the treatment B10N0 ( 3 of 8 measurement events) and B20N0 (6 of 8 measurements) when no nitrogen was applied and in the treatment B20N80 (5 of 8 measurements) when $80 \mathrm{~kg}$ of nitrogen was applied. According to this, the biochar incorporation to soil can be suggested as a possible way to ameliorate soils and may be effective in increasing soil $\mathrm{pH}$.
\end{abstract}

Keywords: biochar, soil pH, Orthic Luvisol, agro-ecosystem

Biochar (black carbon) refers to the aromatic carbon materials produced by pyrolysis of biomass (heating in an oxygen-limited environment at temperatures $400-900{ }^{\circ} \mathrm{C}$ ). There have been reported a lot of positive impacts of biochar as a soil amendment such as mitigating climate change (Lehmann, 2007) through increasing soil carbon storage (Fowles, 2007) while decreasing direct GHG emission and improving soil fertility and crop productivity (Glaser et al., 2001; Major et al., 2010a; Lehmann, 2007; 2008).

In balance to this, biochar application has been shown to have barriers, as well. The barriers are the availability of biochar to farmers (no biochar producers in Slovakia up to now) and, a very important one, the legislative barrier that prevents biochar being applied to land (e.g. in Europe). The lack of biochar inclusion in current agricultural policy is due to the major uncertainty surrounding the long term behaviour of biochar, its potential negative impacts on soil quality, and the fact that it cannot realistically be removed from soil after application.

One of the very important soil chemical properties is soil $\mathrm{pH}$. The $\mathrm{pH}$ of the soil affects the solubility of the substances in the soil, thus their availability for living organisms. The potential liming effect of agricultural residues and other plant materials has been reported (Noble et al., 1996; Tang and Yu, 1999). Decarboxylation of organic anions (as indicated by excess cations or ash alkalinity) of added plant residues consumes protons and thus increases the soil $\mathrm{pH}$ (Yan et al., 1996; Tang and Yu, 1999). Besides this carbon (C) transformation process, nitrogen $(\mathrm{N})$ transformation is thought to be the other main process that has effect on the soil pH fluctuation (Xu and Coventry, 2003; Xu et al., 2006). Ammonification of residue organic $\mathrm{N}$ consumes protons and causes soil $\mathrm{pH}$ to increase, whereas nitrification of mineralized residue nitrogen releases protons and causes soil $\mathrm{pH}$ to decrease. Small increases in soil pH following crop residue addition to soil may act to stimulate nitrification and counteract the alkalinity produced. Hence, addition of offsite liming materials, such as biochar, may offer a possible solution to manage acidity of the agricultural soils.

Biochar application to soils may have agronomic benefits such as neutralizing soil $\mathrm{pH}$ and providing nutrients (Jeffery et al., 2011; Yuan et al., 2011). The pyrolytic process of biochar production converts biomass acids into the biooil component and the alkalinity is inherited by the solid biochar (Laird et al., 2010). Producing biochar at different temperatures causes the increases of their alkalinity with increasing charring temperature (Yuan et al., 2011c). The $\mathrm{pH}$ of biochar is influenced by the type of feedstock used, production temperature and production duration. The effectiveness of liming materials is determined by the $\mathrm{pH}$ buffer capacity of the soil and neutralizing values of the amendments. The effect of biochar on increase of $\mathrm{pH}$ in highly weathered tropical soils had been confirmed (Glaser et al., 2001; 2002). Other studies also showed that the alkalinity of biochars was a key factor affecting their liming potential (Yuan et al., 2011b) and also showing an increase of $\mathrm{pH}$ when biochar with higher $\mathrm{pH}$ value was applied to the acidic soil (Yuan et al., 2011c) with clear increase of soil $\mathrm{pH}$ with increasing biochar application rates (Yuan et al., 2011a). The effect of biochar on soil pH change and mode 
of action need to be studied thoroughly using various biochars (different in type of feedstock used, production temperature and production duration) in various soils of different agro-ecosystems.

The objective of this study was to evaluate the effect of biochar amendment on the $\mathrm{pH}$ of slightly acidic Orthic Luvisol at the research site located in western Slovakia. We hypothesized that the biochar with higher $\mathrm{pH}$ (8.8) has a strong ability to increase the soil $\mathrm{pH}$ of the studied soil with the initial $\mathrm{pH}$ at 5.6 .

\section{Material and methods}

\section{Field site and experimental design}

This field trial was conducted at the experimental site of SAU-Nitra (Nitra - Malanta) in the Nitra region of Slovakia (lat. $48^{\circ} 19^{\prime} 00^{\prime \prime}$; lon. $18^{\circ} 09^{\prime} 00^{\prime \prime}$ ) during March - October, 2014. The soil type is classified as Orthic Luvisol (FAO, 1998). The average annual air temperature was $10.3^{\circ} \mathrm{C}$ and annual precipitation was $640 \mathrm{~mm}$ during the studied year.

Soil samples $(0-10 \mathrm{~cm})$ from 10 random locations (experimental field trial) were taken on $4^{\text {th }}$ of March to get an initial value of soil $\mathrm{pH}$ (in $\mathrm{KCl}$ ) before lying out of experiment ( $7^{\text {th }}$ of March), applying biochar ( $10^{\text {th }}$ of March) and sowing the crop ( $11^{\text {th }}$ of March). The replicated $(n=3)$ trial plots $(4 \times$ $6 \mathrm{~m}$ ) were laid out in a randomized block design and planted with spring barley (Hordeum vulgare L.) in the experimental field that has been used for crop production over the last several years. The experiment (3 replicates) consisted of following treatments separated by a protection row $0.5 \mathrm{~m}$ in width (Figure 1):

T1. BONO - soil

T2. B10N0 - soil + biochar (10 $\left.\mathrm{t} \mathrm{ha}^{-1}\right)$

T3. B20NO - soil + biochar $\left(20 \mathrm{t} \mathrm{ha}^{-1}\right)$

T4. B0N40 - soil + fertilizer (40 kg N ha-1)

T5. B10N40 - soil + fertilizer $(40 \mathrm{~kg} \mathrm{~N} \mathrm{ha-1)} \mathrm{+} \mathrm{biochar}$ $\left(10\right.$ t ha $\left.^{-1}\right)$

T6. B20N40 - soil + fertilizer $\left(40 \mathrm{~kg} \mathrm{~N} \mathrm{ha}^{-1}\right)+$ biochar $\left(20\right.$ t ha $\left.^{-1}\right)$

T7. B0N80 - soil + fertilizer $\left(80 \mathrm{~kg} \mathrm{~N} \mathrm{ha}^{-1}\right)$

T8. B10N80 - soil + fertilizer $\left(80 \mathrm{~kg} \mathrm{~N} \mathrm{ha}^{-1}\right)+$ biochar $\left(10\right.$ t ha $\left.^{-1}\right)$

T9. B20N80-soil + fertilizer $\left(80 \mathrm{~kg} \mathrm{~N} \mathrm{ha}{ }^{-1}\right)+$ biochar $\left(20\right.$ t ha $\left.^{-1}\right)$

\section{Biochar characterization and $\mathrm{pH}$ measurements}

Biochar used for the field experiment was produced from paper fiber sludge and grain husks (1: $1 \mathrm{w} / \mathrm{w}$ ) (company Sonnenerde, Austria) by pyrolysis at $550{ }^{\circ} \mathrm{C}$ for 30 minutes in a Pyreg reactor (Pyreg GmbH, Dörth, Germany) (Table 1).

The soil $\mathrm{pH}(\mathrm{KCl})$ at depth $0-10 \mathrm{~cm}$ was measured once a month (March - October, 2014) in soil: $1 \mathrm{M} \mathrm{KCl}$ solution ( $1: 2.5)$ following shaking suspension for 30 minutes using a pH meter (HI 2211, HANNA Instruments, RI, USA).

\section{Statistical analysis}

The statistical processing of the data included the determination of means and standard deviations. One-way

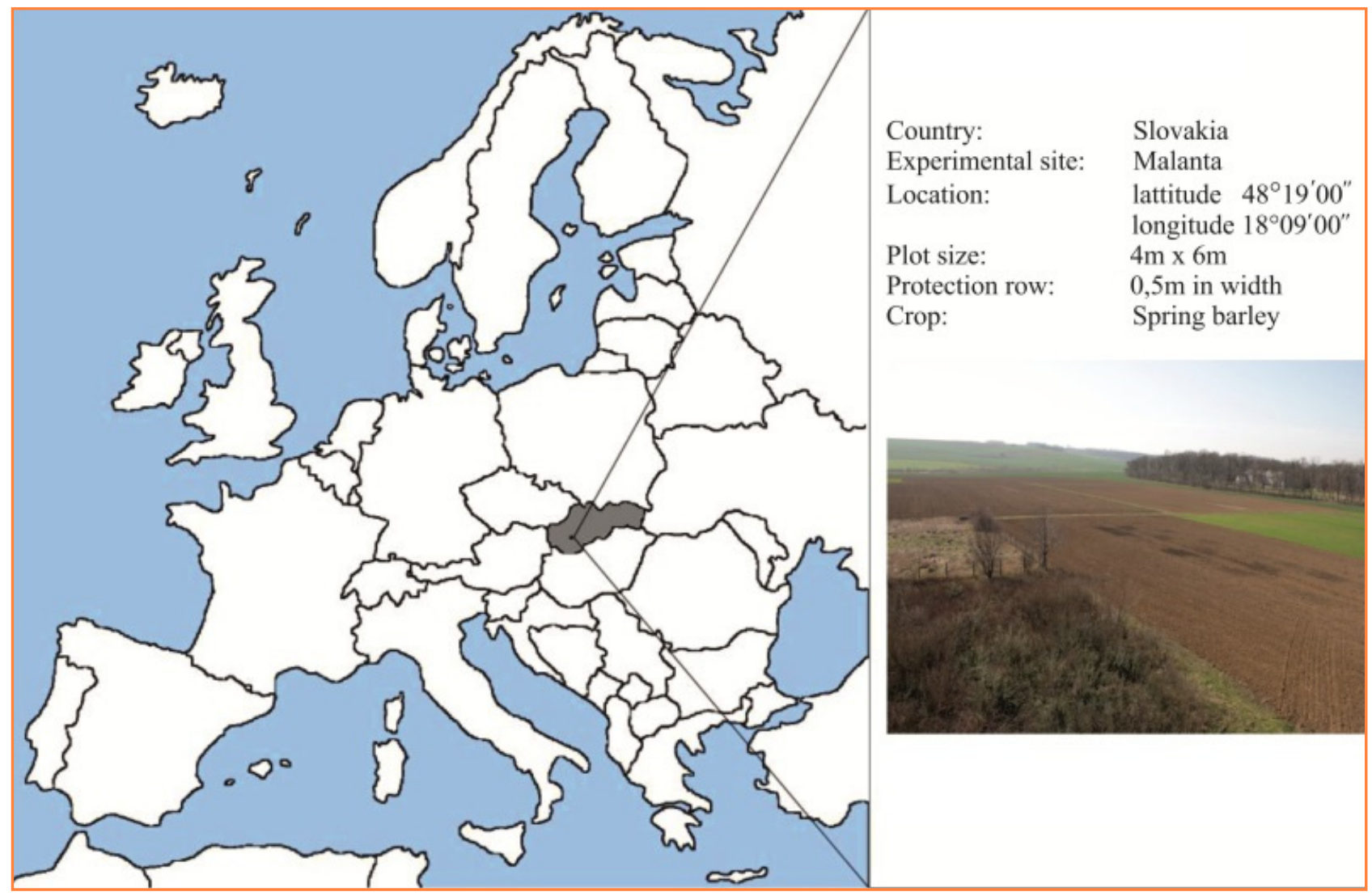

Figure 1 Field site and the aerial view on the field plots 
Table 2

Basic chemical and physical properties of the biochar (biochar certificate Nr. 1013069001 provided by company Sonnenerde, Austria)

\begin{tabular}{|l|c|c|}
\hline \multicolumn{2}{|c|}{ Biochar } \\
\hline pH & $\mathrm{KCl}$ & 8.8 \\
\hline Ca & $\mathrm{g} \mathrm{kg}^{-1}$ & 57 \\
\hline Mg & $\mathrm{g} \mathrm{kg}^{-1}$ & 3.9 \\
\hline $\mathbf{K}$ & $\mathrm{g} \mathrm{kg}^{-1}$ & 15 \\
\hline Na & $\mathrm{g} \mathrm{kg}^{-1}$ & 0.7 \\
\hline Total C & $\mathrm{g} \mathrm{kg}^{-1}$ & 53.1 \\
\hline Total N & $\mathrm{g} \mathrm{kg}^{-1}$ & 14 \\
\hline C/N & - & 37.9 \\
\hline SSA & $\mathrm{m}^{2} \mathrm{~g}^{-1}$ & 21.7 \\
\hline Ash & $\%$ & 38.3 \\
\hline
\end{tabular}

analysis of variance (ANNOVA) at $p$ $<0.05$ was performed to examine the effect of biochar at different application rates on soil $\mathrm{pH}$. Significant differences between means of three replications were identified using a least significant difference (LSD at $p<0.05$ ) test using STATGRAPHICS Centurion statistical software.

\section{Results and discussion}

Figures $2-4$ presents soil $\mathrm{pH}$ change of all treatments during the 8 month field experiment at the experimental site of SAU-Nitra (Nitra-Malanta) in the Nitra region of Slovakia. The average initial soil $\mathrm{pH}$ before applying biochar was 5.6.

Biochar applied at 10 and $20 \mathrm{t} \mathrm{ha}^{-1}$ without mineral fertilizer application immediately increased soil $\mathrm{pH}$ (March measurements) by 0.35 and 0.59 unit for BC10NO and BC20NO, respectively compared to control (BCONO). This trend continued to the end of the experiment for both biochar treatments with the magnitude of soil $\mathrm{pH}$ increase in the order: BCONO $>$ BC10NO > BC20N0. Application of $10 \mathrm{t} \mathrm{ha}^{-1}$ of biochar (B10N0) increased soil $\mathrm{pH}$ by $0.13-0.56$ with significant increase $(p<0.05)$ found in May, July and September ( 3 of 8 measurement events) as compared to control. The magnitude of soil $\mathrm{pH}$ increase was even larger with the higher biochar application rate (B20N0) where the soil $\mathrm{pH}$ increased by $0.47-0.78$ during all months with a significant increase $(p<0.05)$ from May to October (6 of 8 measurements). Comparison of the $\mathrm{pH}$

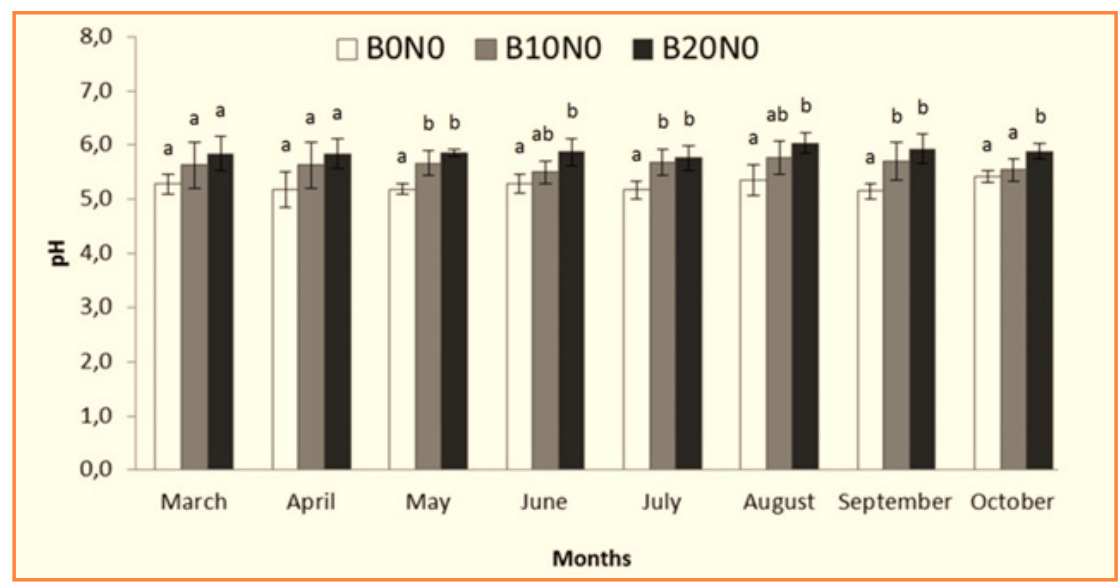

Figure 2 Soil pH during the field experiment (March - October, 2014) on Orthic Luvisol planted with spring barley amended with biochar and no nitrogen fertilizer in 2014 ( \pm standard deviation, $n=3$ ). Different letters indicate significant difference between treatments means by the LSD test $(p<0.05)$

values at the beginning and the end of the experiment (temporal change) within each treatment showed different results. The soil $\mathrm{pH}$ in control treatment (BONO) in October was higher by 0.14 units compared to control value of soil $\mathrm{pH}$ at the beginning of experiment (March). Similar trend was found in the treatment B20N0 with higher $\mathrm{pH}$ in October by 0.04 units compared to $\mathrm{pH}$ value in March. Opposite was found in case of B10N0 where the soil $\mathrm{pH}$ in October was lower by 0.08 as compared to $\mathrm{pH}$ in March.

In the treatments with the medium level of $\mathrm{N}$ fertilization ( $40 \mathrm{~kg} \mathrm{~N} \mathrm{ha}{ }^{-1}$ ) was found that the average soil $\mathrm{pH}$ immediately increased with similar trend to the end of the experiment as compared to biochar application rates (BC10N40, BC20N40) (Figure 3). However, there was not found any significant difference $(p<0.05)$ between both biochar treatments (BC10N40, BC20N40) as compared to the control (BON40) during the whole studied period. Also, the magnitude of average soil $\mathrm{pH}$ increase was not always in the order: BCON40 > $\mathrm{BC} 10 \mathrm{~N} 40>\mathrm{BC} 20 \mathrm{~N} 40$ as it was found in the biochar treatments with no $\mathrm{N}$ fertilizer application (Figure 2 and 3). Application of both biochar rates (10 and $20 \mathrm{t} \mathrm{ha}^{-1}$ ) increased soil $\mathrm{pH}$ by $0.43-0.85$ and by $0.53-0.87$ for $\mathrm{B} 10 \mathrm{~N} 40$ and $\mathrm{B} 20 \mathrm{~N} 40$, respectively as compared to BON40. Temporal change of soil $\mathrm{pH}$ within treatments showed no change in the treatment B0N40 and B20N40 when comparing $\mathrm{pH}$ values of March and October. The soil $\mathrm{pH}$ in $\mathrm{B} 10 \mathrm{NO}$ in October was lower by 0.05 units compared to $\mathrm{pH}$ value in March.

In the treatments with the higher level of $\mathrm{N}$ fertilization ( $80 \mathrm{~kg} \mathrm{~N} \mathrm{ha}^{-1}$ ) it was found that the biochar applied at 10 and 20 t ha $^{-1}$ immediately increased soil $\mathrm{pH}$ (March measurements) by 0.66 and 0.93 unit for $\mathrm{BC} 10 \mathrm{~N} 80$ and $\mathrm{BC} 20 \mathrm{~N} 80$, respectively compared to $\mathrm{BCON} 80$ (Figure 4). This trend continued to the end of the experiment for both biochar treatments with the magnitude of soil $\mathrm{pH}$ increase in the order: BON80 > BC10N80 > BC20N80. Similar was found also in the treatments which were not fertilized. Application of $10 \mathrm{t} \mathrm{ha}^{-1}$ of biochar increased soil $\mathrm{pH}$ by $0.49-0.67$ with no significant increase $(p<0.05)$ found compared to control plots 


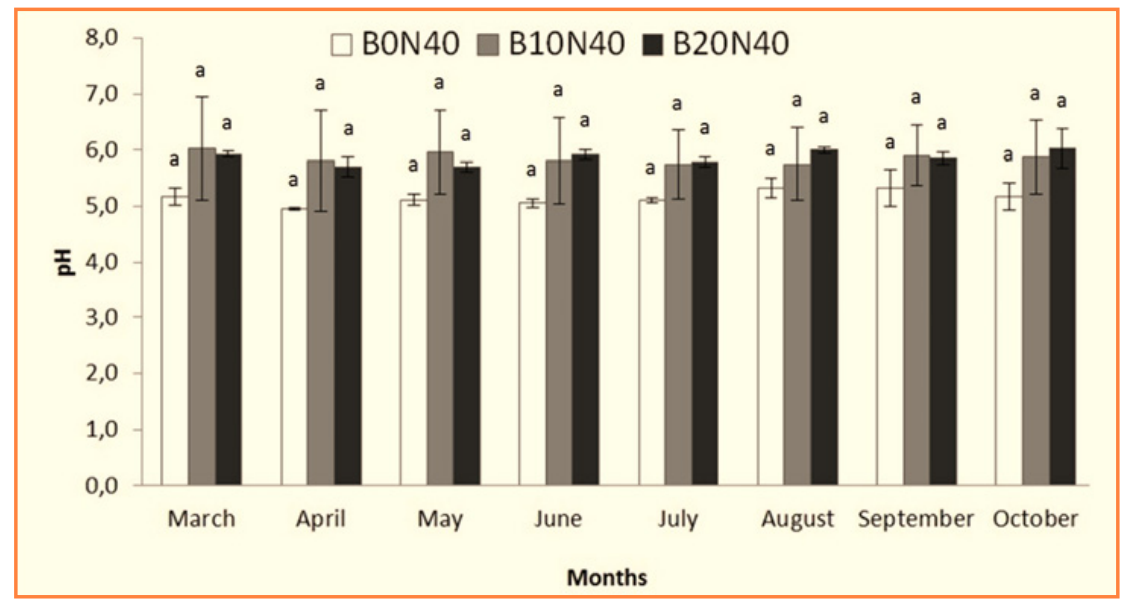

Figure 3 Soil pH during the field experiment (March - October, 2014) on Orthic Luvisol planted with spring barley amended with biochar and fertilized with $40 \mathrm{~kg} \mathrm{~N} \mathrm{ha}^{-1}$ in 2014 ( \pm standard deviation, $n=3$ ). Different letters indicate significant difference between treatments means by the LSD test $(p<0.05)$

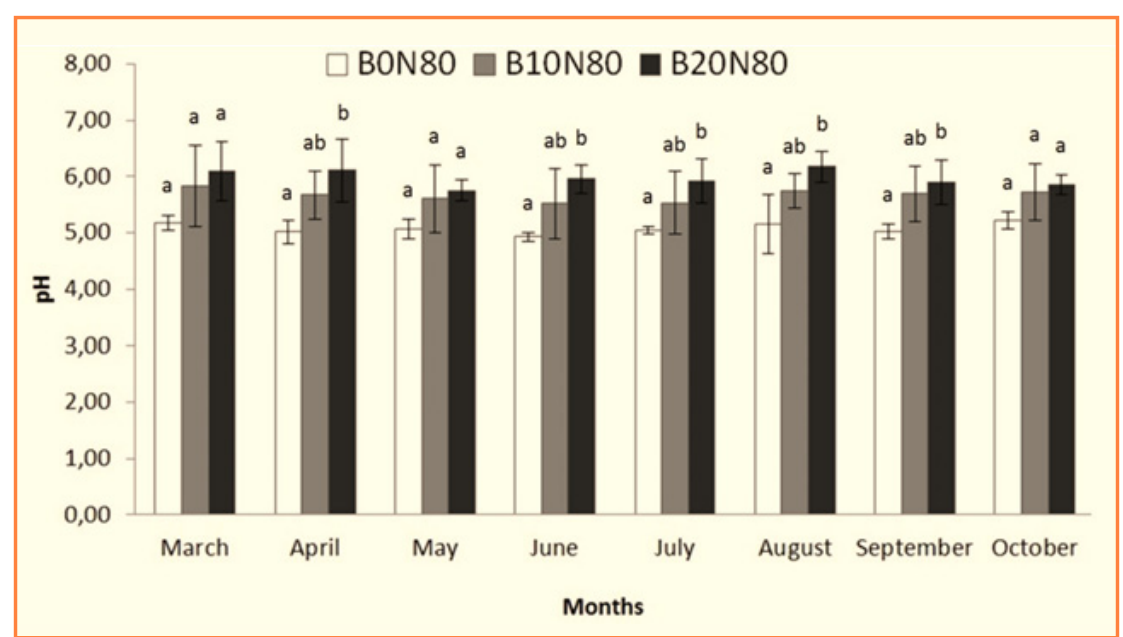

Figure 4 Soil pH during the field experiment (March - October, 2014) on Orthic Luvisol planted with spring barley amended with biochar and fertilized with $80 \mathrm{~kg} \mathrm{~N} \mathrm{ha}^{-1}$ in 2014 ( \pm standard deviation, $n=3$ ). Different letters indicate significant difference between treatments means by the LSD test $(p<0.05)$

during the whole period. However, the magnitude of the increase was larger for the higher biochar application rate $\left(20 \mathrm{t} \mathrm{ha}^{-1}\right)$ where the soil $\mathrm{pH}$ increased by 0.62-1.09 during all months with a significant increase $(p<0.05)$ from April to September except of May (5 of 8 measurement events). Temporal change of soil $\mathrm{pH}$ within treatments showed that the soil $\mathrm{pH}$ in control treatment (BONO) in October was higher by 0.05 units compared to the control value of soil $\mathrm{pH}$ at the beginning of experiment (March). Opposite was found in case of both biochar treatments. The soil $\mathrm{pH}$ in October was lower by 0.11 and 0.25 unit for $\mathrm{BC} 10 \mathrm{~N} 80$ and $\mathrm{BC} 20 \mathrm{~N} 80$,

respectively compared to $\mathrm{pH}$ values at the beginning of experiment.

Other scientific studies also showed an increase of $\mathrm{pH}$ when biochar with higher $\mathrm{pH}$ value was applied to the acidic soil (Yuan et al., 2011c) with clear increase of soil $\mathrm{pH}$ with increasing biochar application rates (Yuan et al., 2011a). In previous studies, the increase in soil $\mathrm{pH}$ caused by organic material amendment was mainly attributed to organic anions present in the materials, and this was indicated by the concentration of excess cations over inorganic anions, that is, ash alkalinity (Yan et al., 1996). Hence, after biochar addition into soil, organic anions can undergo decarboxylation and consume protons. Additionally, organic anions and other negatively charged functional groups present in organic matter can undergo association reactions with $\mathrm{H}+$ ions (Tang and Yu, 1999; Xu et al., 2006). Therefore, it is expected that in this study, both of these processes are likely to contribute to the increases in soil $\mathrm{pH}$ after biochar application.

\section{Conclusions}

According to evaluation of the data it can be concluded that incorporation of biochar to the slightly acidic soils was an effective way to increase soil pH up to at least 8 months after application in case of all biochar and fertilization treatments. Thus, our hypothesis that the biochar with higher $\mathrm{pH}$ (8.8) has a strong ability to increase the soil $\mathrm{pH}$ of the studied soil with the initial $\mathrm{pH}$ at 5.6 was confirmed. This indicates that a single biochar application may provide benefits at least over one year cropping season, however, long-term field studies are still lacking and needed to determine when a steady state is reached or if and when a decline starts to occur. The results also indicate that magnitude of soil $\mathrm{pH}$ would be increased by increasing biochar application rates, which was found in case of no nitrogen applied and in case of higher nitrogen application rate. Therefore, biochar could be suggested as a valuable tool for the management of agroecosystems and a plausible way to ameliorate soils and may be effective in increasing soil $\mathrm{pH}$.

\section{Acknowledgement}

This study was supported by Slovak Grant Agency - VEGA, No. 2/0013/15; VEGA, No. 1/0136/12 and Slovak Research and Development Agency under the contract No. APVV-0512-12.

\section{References}

FOWLES, M. 2007. Black carbon sequestration as an alternative to bioenergy. In Biomass Bioenergy, vol. 31, 2007, pp. 426-432.

GLASER, B. - HAUMAIER, L. GUGGENBERGER, G. - ZECH, W. 2001. The Terra Preta phenomenon: a model for sustainable agriculture in the humid tropics. In Naturwissenschaften, vol. 88, 2001, pp. 37-41. 
GLASER, B. - LEHMANN, J. - Zech, W. 2002. Ameliorating physical and chemical properties of highly weathered soils in the tropics with charcoal. In Biol. Fert. Soils., vol. 35, 2002, pp. 219-230.

GLASER, B. 2007. Prehistorically modified soils of central Amazonia: a model for sustainable agriculture in the twenty-first century. In Phil. Trans. Roy. Soc. B., vol. 362, 2007, pp. 187-187.

JEFFERY, S. - VERHEIJEN, F. - VAN DER VELDE, M. - BASTOS, A. 2011. A quantitative review of the effects of biochar application to soils on crop productivity using meta-analysis. In Agriculture, Ecosystems \& Environment, vol. 144, 2011, pp. 175-187.

LAIRD, DA. - FLEMING, P. - DAVIS, DD. - HORTON, R. - WANG, B. KARLEN, DL. 2010. Impact of biochar amendments on the quality of a typical midwestern agricultural soil. In Geoderma, vol. 158, 2010, pp. 443-449.

$L A L, R$. 2009. Soil degradation as a reason for inadequate human nutrition. In Food Sec., vol. 1, 2009, pp. 45-57.

LEHMANN, J. - PEREIRA DA SILVA, J. - STEINER, C. - NEHLS, T. ZECH, W. - GLASER, B. 2003. Nutrient availability and leaching in an archaeological Anthrosol and a Ferralsol of the Central Amazon basin: fertilizer, manure and charcoal amendments. In Plant Soil. vol. 249, 2003, pp. 343-357.

LEHMANN, J. 2007. Bio-energy in the black in Front. In Ecol. Environ., vol. 5, 2007, pp. 381-387.

LEHMANN, J. - SOHI, S. 2008. Comment on fire-derived charcoal causes loss of forest humus. In Science, vol. 321, 2008, pp. 1295

MAJOR, J. - LEHMANN, J. - RONDON, M. - GOODALE, C. 2010. Fate of soil-applied black carbon: downward migration leaching and soil respiration. In Global Change Biol., vol. 16, 2010, pp. 1366-1379.

NOBLE, AD. - ZENNECK, I. - RANDALL, PJ. 1996. Leaf litter ash alkalinity and neutralisation of soil acidity. In Plant and Soil, vol. 179 1996, pp. 293-302.

NOVOTNY, EH. - HAYES, MHB. - MADARI, BE. - BONAGAMBA, TJ. AZEVEDO, ER. - SOUZA, AA. 2009. Lessons from the Terra Preta de
Indios of the Amazon region for the utilisation of charcoal for soil amendment. In J. Brazil. Chem. Soc., vol. 20, 2009, pp. 1003-1010.

ÖZÇIMEN, D. - KARAOSMANOĞLU, F. 2004. Production and characterization of bio-oil and biochar from rapeseed cake. In Renewable Energy, vol. 29, 2004, pp. 779-787.

TANG, C. - YU, Q. 1999. Impact of chemical composition of legume residues and initial soil $\mathrm{pH}$ on $\mathrm{pH}$ change of a soil after residue incorporation. In Plant and Soil, vol. 215, 1999, pp. 29-38.

XU, RK. - COVENTRY, DR. 2003. Soil pH changes associated with lupin and wheat plant materials incorporated in a red-brown earth soil. In Plant and Soil, vol. 250, 2003, pp. 113-119.

XU, JM. - TANG, C. - CHEN, ZL. 2006. The role of plant residues in $\mathrm{pH}$ change of acid soils differing in initial $\mathrm{pH}$. In Soil Biology \& Biochemistry, vol. 38, 2006, pp. 709-719.

YAN, F. - SCHUBERT, S. - MENGEL, K. 1996. Soil pH increase due to biological decarboxylation of organic anions. In Soil Biology and Biochemistry, vol. 28, 1996, pp. 617-624.

YUAN, JH. - XU, RK. - ZHANG, H. 2011. The forms of alkalis in the biochar produced from crop residues at different temperatures. In Bioresource Technology, vol. 102, 2011, pp. 3488-3497.

YUAN, J. - XU, R. - QIAN, W. - WANG, R. 2011a. Comparison of the ameliorating effects on an acidic ultisol between four crop straws and their biochars. In J. Soil. Sediment, vol. 11, 2011, pp. 741-750.

YUAN, J. - XU, R. - WANG, N. - LI, J. 2011b. Amendment of acid soils with crop residues and biochars. In Pedosphere, vol. 21, 2011, pp. 302-308.

YUAN, J. - XU, R. - ZHANG, H. 2011c. The forms of alkalis in the biochar produced from crop residues at different temperatures. In Biores. Technol., vol. 102, 2011, pp. 3488-3497. 